\title{
MISCELLANTA GEOGRAPIICA
}

WARSZAWA 1990

\section{Stefan Kałuski}

\section{PROBLEMS OF DELIMITATION AND TYPOLOGY OF BORDER REGIONS}

Problems connected with political borders and border areas are a subject of interest to many branches of science e.g. history, politology, international law, geography. The growing interest in questions of frontiers and border regions is stimulated by political, social and economic changes in the modern world. In Western Europe it is connected with the intended changes of the function of borders in the Common Market States after 1990. In Middle and South-eastern Europe an animation in various forms of cooperation can be observed in border regions. In developing countries there is the essential problem of precise demarcation of many border sections and creating an outline of cooperation in border regions. In the recent years geographers manifested their interest in those problems by organizing, among others, a number of international conferences ${ }^{1}$ devoted to those questions. During all those symposia the insufficiency of methodological work was insisted on. Problems of definition, delimitation and typology of border regions were pointed out.

In the present paper an evaluation has been shown of four different and most often used definitions of border regions, the problems of their delimitation, as well as the author's own, may be controversial, conception of interpreting border regions and their delimitation. Laoking up the definition of "border regions" in encyclopaedias and dictionaries we find one clear regularity: those regions are defined as areas where special rules aimed at the protection of the State border are in force. They usually specify the rules of permanent or temporary stay of the State's citizens and foreigners in those areas, the principles of using border waters for sports and tourism, the possibilities of taking photos,

1 I can mention three of them: Internationales Symposium „Grenze und Kulturlandschaft", Basel 1981; Simposio Frontierizas en America Latina, Warszawa-Wykno 1987; Conference on „Granice i pogranicza - problemy społeczne, polityczne i gospodarcze" (Borders and border regions - social, political and economic problems), Łódź 1988. 
etc. There are opinions that the more friendly the relations between adjacent countries the less rigorcus the laws in force within those areas. Sometimes in so defined border regions, still several zones are distinguished (at different distances from the frontier) e.g. in Poland the border road band, the border zone, the frontier line. Such definitions usually created by lawyers are of limited interest to geographers, though those rules have undoubtedly effect on economic activities and the specific character of these areas. The advantage of such a definition is a precise determination of the territorial extent of those areas.

Another way of interpreting the notion of "border region" is its identification with the territorial extent of administrative units of the first or second rank adjoining the State frontier. The adoption of this definition is convenient for all kinds of geographical research mainly because of the facility of getting statistical data concerning such areas. However, it should be rememberd how different factors and considerations decide on the shape of the "internal" border of such units. A border area separated in this way may take up a varying percentage of a country's surface, e.g. in Poland eighteen border voivodships cover $40 \%$ of the country's surface. In most Latin American countries first rank administrative units adjoining state borders cover over the half of their territories. In Austria such units, the so-called union lands, cover over $99 \%$ of the surface, for only one of them-Vienne-does not adjoin the State's frontiers. The larger surface of the country and the smaller administrative units considered the lower is the surface percentage of border areas. If the country is small and first rank administrative units are involved the situation will be inverse. Thus the acceptance of this definition will apply at a limited degree to comparative research and also to countries having a large number of islands.

Another possibility of the interpretation of border region is to treat it as a specific economic area, which is often an area of lower economic activity. Such a situation is due to a number of historical and natural factors and to political and administrative decisions. That situation is usually manifested by a lower dentisity of population, a lower degree of urbanization, a less developed system of communication. But there exist areas where the State frontier is an essential factor of economic activation of the adjacent regions. Such is the case of frontiers between Switzerland and Italy or Austria, Austria and Yugoslavia, running across touristically attractive Alpine areas, where facilities in international traffic favour visiting by people on holiday in one country the border regions of a neighbouring country. The functioning of such areas on the border line between Yugoslavia and Austria has been presented in an interesting manner by V. Klemencic. A disadvantage of interpreting 
area as an economic region is a subjective selection of features according to which the region has been separated. It should also be noticed that there may be the fargoing identity of interests in economic activity in those neighbouring areas, but there also may appear different or even colliding tendencies. Such doubts have led to still another conception of interpreting the border region. In the face of difficulties in defining the notion it is accepted in the same way as the notion of "region" i.e. as an instrument of investigation, helping to analyse facts. A border region can be distinguished if we state an essential influence of the border on relatively stable changes of economic structure resulting from the fact of the existence of that border.

The definition and the way of delimitation of the border region proposer by the present author is connected with the controversial division of political frontier into natural and artificial ones. The common meaning of a natural frontier is a frontier running along mountain ranges, rivers, lakes, deserts or marshes. The division of frontiers into natural and artificial has been criticized using various arguments (Maul 1956) Rejecting philosophical and methodologic conceptions of geographical determinism most geographers are no more investigating natural conditions of the course and function of political frontiers fearing to be accused of deterministic ideas. The reluctance to use the term "natural border" may also result from the fact that this notion is used and abused in geopolitics. The most frequent argument against the term of "natural frontiers" is the fact that it is no more up-to-date since they have lost their strategic importance in times of developed military technique, particularly of air force and rocket weapons. Their importance as communication barrier is also decreasing. However, if another interpretation of the natural border is assumed-that as a complex of natural resources which can be economically used in common by the adjacent countries-the notion becomes pertinent and up to date. It concerns river systems, lakes, even subsoil water, forest areas cut by political frontiers. The extent of the border region adjoining a natural frontier interpreted in this way can be delimited, for example, by watersheds of border rivers, limits of forest complexes or of marshes, etc.

It should be noticed that problems connected with the exploitation not only of border rivers but of whole river systems are studied not only by geographers or by specialists of water management but also by lawyers: thay propose to replace the term "border river" or "international river" by the term "international drainage basin" (Garretson Hayton 1967). This term has been accepted in a number of multilateral international contracts negotiated lately and concerning, among others, 
such rivers as the Senegal, the Niger, La Plata, or Saint Lawrence River. The concluded agreements facilitate the coordination of all investment proceedings over the drainage basin, the faight against river pollution, flood control. It is amazing that the term "international drainage basin" has not been used yet in any agreement concerning European rivers though, on this continent, the total leng of border rivers is about 1000 kilometres (Register 1978).

Assuming that large forest complexes also constitute a natural border it should be noticed that in many countries they are situated precisely in border areas. This often results from the fact that border areas were not attractive for settlement and location of industry. In Poland, for instance, forests cover ca. 27\% of the country's surface but in five border voivodships they occupy over $40 \%$. Here the international cooperation is much less attractive than e.g. in water management. In many areas, where the frontier crosses forest complexes, up to now no actions have been agreed upon aimed at the pratection of forest against natural pest and no rules of cooperation in extinguishing fires etc. The problem is of great importance as it frequently concerns the most valuable forest resources of numerous countries.

Much has been already done for nature preservation in border areas. Observing on maps the distribution of national parks we can notice that their territories often border on each other on both sides of the State frontiur. Their managers usually coordinate common rules of nature preservation, research etc. Here are a few examples: Glacier Park and Waterton Lakes National Park in USA and Canada; La Vanoise and Gran Paradise in France and Italy; in Poland the Tatra, the Pieniny, the Karkonosze and the Bialowieza National Parks adjoining territiries of national parks in Czechoslovakia and in the Soviet Union; the Wirunga National Park in the Republic of Zair and the Volanic National Park in Rwanda.

Many countries have lately undertaken actions aiming at draining marshes in border regions or at the activation of desert areas.

The observation of those actions leads to the conclusion that the division of borders into natural and artificial ones is correct but it has changed its meaning. Natural borders have irrevocably lost their strategic intportance and their role of barrier for communication is decreasing. Instead, coordinated actions become indispensable in water management of drainage basin of border rivers; in the environment preservation and formation within areas of mountains, forests, marshes and deserts which are crossed by frontiers and which are particularly previous to human interference. The delimitation of border regions according to the extent of those elements of the natural environment seems 
to be logically justified and socially useful. The argument for it is the necessity of preservation and formation of the environment in border areas which often have great natural and economic values. Those areas may become a grateful subject for international geographical research.

\section{REFERENCES}

Garretson, A.H., Hayton, R., 1967, The Law of International Drainage Basins, New York.

$\mathrm{M}$ a u l, O. 1956, Politische Geographie, Berlin.

Register of International Rivers, 1978, Pergamon Press, Oxford. 
